\title{
Effect of Organic Fertilizers and Complete Chemical Fertilizers (Nitrogen, Phosphorus, Potassium) on Green Onions Growth and Yield
}

\author{
Nouri Kushlaf1* ${ }^{\star}$, Ahlam Rashed ${ }^{1}$, Khalifa.S.Mohamed², A.M.EL-mahmoudy ${ }^{1}$, Nadia Almunir ${ }^{1}$, Manal M Elshili¹,
} Seham T M Oshkondali3

FFaculty of Science/Zawia University

${ }^{2}$ Faculty of Science/Gharyan University

3Faculty of Medicine/Zawia University

*Corresponding Author

Nouri Kushlaf

\section{Article History}

Received: 24.09.2019

Accepted: 02.10 .2019

Published: 20.10.2019

\begin{abstract}
This study was conducted at a private farm in Zawia Libya during the winter of 2015/2016 to study the effect of organic fertilizer (decomposed sheep residues) and complete chemical fertilizers (nitrogen, phosphorus, potassium) on vegetative growth and yield of green onion class (Texas SR502), which cultured in sandy soil. The results showed that the significant effect of the type and concentration of the fertilizer which has been used, so the organic fertilizer of the decomposed sheep remnants by 20 tons / ha concentration revealed significant effect on studied characteristics, while there is no significant effect by using 10 tons/ha of organic fertilizer in comparison with the control except it is effect on the diameter of the bulb. Also, the results showed that there were no significant differences between the three fertilizer treatments on the percentage of total soluble solids contents of the crop. However, there were a significant difference between them and the control.
\end{abstract}

Keywords: Organic farm Chemical Fertilizers.

\section{INTRODUCTION}

Onion (Allium cepa L) is classified as a vegetable crop of the Amary llidaceae family. It contains more than 90 plant species and it is followed by 1200 species. It is believed that the native place to be northern Iran or the region stretching from Palestine to India [1]. It is one of the most important strategic crops in Libya and the world, which is consumed in large quantities and is characterized by its nutritional, medical and economic value. It contains good proportions of vitamins $\mathrm{C}$ and $\mathrm{K}$, proteins, iron and calcium elements, while its medical importance lies in containing kerstin, which is of great importance as an antioxidant and anticancer [2]. In addition, the onion contains biological and chemical compounds, that make it is consumption has medical and health properties [3]. Also, the most abundant of these materials is a group of organic sulfur compounds, especially the medicinal substance, Glutathione [4]. Therefore, onions are an essential ingredient in many health programs including weight loss programs, preventive diet programs against vascular, cardiovascular diseases and immune dysfunction [5,6]. Therefore, the different countries have sought to cultivate and increase the cultivated areas to increase the level of production. The onion planted in Libya is estimated at 11.5 thousand hectares producing an estimated 207 thousand tons [7]

Many studies confirm that the growth of most vegetable crops, including onions, is improved by treating them with different organic fertilizers, such as sheep, cattle and poultry residues. Organic fertilizers improve soil properties, in addition to being a good source of nutrients; they contain all the major nutrients. It is evident by its significant effect on dry matter ratio, onion quality and total yield per hectare $[8,9]$. In addition, some studies in Egypt indicated that the use of organic fertilizers and various addition methods, either spraying on vegetative or terrestrial growth, and their addition in the form of doses, positively affect the quantity and quality of onions produced [10]. Blay et al. [11] also found that the addition of poultry manure at a rate of 40 tons / ha gave a significant increase in plant height and number of leaves per plant. Abdelrazzag [12] also showed that the addition of sheep and poultry manure at a rate of 20 tons / ha to the Giza onion plant gave the highest leaf area and the highest yield of bulbs. Moreover, Aisha et al.[13] establish that when fertilizer was added, the fertilizer of urban waste (5 and 10 tons / ha) showed that the rate of 10 tons / ha gave the longest

Copyright @ 2019: This is an open-access article distributed under the terms of the Creative Commons Attribution license which permits unrestricted use, distribution, and reproduction in any medium for non commercial use (NonCommercial, or CC-BY-NC) provided the original author and source are credited. 
plant height, the highest number of leaves, significant increase in wet and dry weight of the plant and the highest yield of bulbs, as well as the length, diameter and weight of bulb and the percentage of total dissolved solids. In a study conducted by kushlaf et al. [14] to find out the effect of the integrated chemical fertilizer, bio-fertilizer nitropine and organic fertilizer sheep manure and some inter-effect on growth characteristics of onion yield and quality of onion bulbs Texas class 502 . It was found that the addition of triple treatment of each Chemical fertilizer + bio-fertilizer (nitropine) + organic fertilizer (sheep manure) has been given a significant increase in the characteristics of vegetative growth for the yield and quality of bulbs in both growing seasons. Also there is a significant effect of organic fertilizer 10 tons / ha in comparison with the control. Moreover, when using poultry manure at 0,2,4,6,8 and 10 tons / ha, there was a significant increase in the length, diameter and weight of the growing seedlings after ten weeks of planting and the increase was directly proportional to the increase in the amount of fertilizer added [15]. Akoun [16] found that when adding fertilizer to the onion plant at 5.6, 11.2 and 22.4 tons / ha, there was an increase in the number of leaves and leaf area of the plant with a gradual increase in the fertilizer used. In addition, when using different levels of farm waste and poultry manure in Giza 6 onion class, the addition treatment of 23.8 tons / ha of farm fertilizer with 47 tons / ha of poultry manure gave the best results in bulb diameter, soft and dry weight of plant and yield as well as total amount of bulbs [16]. Yassen, A.A. and K. A. Khalid [24, 17] observed that when different levels of farm residue and poultry manure used with the Giza 6 onion class by using additional treatment of 23.8 ton/ha of farm residue with 47 ton/ha of poultry manure. There were gave the best results in diameter, wet and dry weight of the plant, also in the total amount of bulbs. Zedan K. G [18] observed a significant increase in plant height, soft plant weight and bulb length when onion fertilized with sheep manure at a rate of 24 tons / ha. This study aims to answer questions. Is the productivity of the organically grown unit area different from that planted by conventional methods? Are the production costs per unit area of organically grown areas differing from those cultivated by conventional methods? What is the effect of organic fertilizers on the quality characteristics of green onions?

\section{Materials ANd Methods}

This study was conducted at a private farm in Zawia, Libya during the winter season 2015/2016 to study the effect of organic fertilizer (decomposed sheep residues) and complete chemical fertilizers (nitrogen, phosphorus, potassium) on vegetative growth and yield of green onion cultivars class (Texas SR502) under sandy soil conditions. The result of the chemical analysis of the components of the field soil as shown in Table 1

Table-1: Chemical analysis of a sample of an experimental field soil

\begin{tabular}{|l|l|}
\hline Parameter Assessed & The proportion of presence \\
\hline Nitrogen & $87 \mathrm{ppm}$ \\
\hline Potassium & $114 \mathrm{ppm}$ \\
\hline $\mathrm{PH}$ & 7.5 \\
\hline Organic Materials (DM) & $0.07 \%$ \\
\hline Translation of salinity (CEC) & $18.0 \mathrm{mg} / \mathrm{g}$ soil \\
\hline
\end{tabular}

Organic fertilizer was then added to decomposed sheep at once during soil preparation and the chemical analysis of the organic fertilizer showed in table (2).

Table-2: Shows the result of chemical analysis of compost

\begin{tabular}{|l|c|}
\hline \multicolumn{1}{|c|}{ Parameter Assessed } & The proportion of presence \\
\hline $\mathrm{PH}$ & 6.7 \\
\hline Degree of electrical conductivity (EC) & 3.6 \\
\hline Total organic carbon & 26.6 \\
\hline Total Nitrogen & $0.85 \%$ \\
\hline Total Potassium & $0.31 \%$ \\
\hline Total phosphorus & $0.43 \%$ \\
\hline Carbon to nitrogen ratio & $1.33 \%$ \\
\hline Ash & $6.11 \%$ \\
\hline Humidity & $54.0 \%$ \\
\hline
\end{tabular}

Seedlings were obtained from an adjacent nursery at the age of 75 days and the seedlings were planted on 15/12/2016 lines (line length $3 \mathrm{~m}$ and the distance between the line and the other $0.60 \mathrm{~m}$ ) and planting in the middle of the line and the distance between the plant and the other $0.1 \mathrm{~m}$, each experimental unit included four lines With an area of $5.4 \mathrm{~m}^{2}$ and the plant density is about 166666 plants / hectare, the service of the field of irrigation and weeding by manual method continued as needed and after 100 days of transplanting the plants were removed from all experimental units.

\section{The experiment involved the following transactions}

Comparative treatment: (without organic or chemical). 


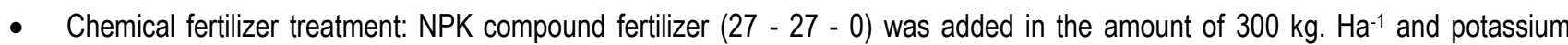
sulfate (K41\%) in the amount of $100 \mathrm{~kg}^{-\mathrm{Ha}^{-1}}$ to the soil before planting.

- $\quad$ Degraded sheep residue of 10 tons. $\mathrm{Ha}^{-1}$ was added to the soil before planting and mixed with it.

- Degraded sheep residue of 20 tons. $\mathrm{Ha}^{-1}$ was added to the soil before planting and mixed with it were recorded:

After 100 days of transplantation, three plants from each experimental unit were randomly taken and the following data

- $\quad$ Plant Length (cm): Measurement by tape measure from the soil surface to the end of the longest leaf in the plant.

- Number of plant tubular leaves: Calculation of tubular blades of randomly selected plants in the experimental unit.

- Foliar area (DSM2): Foliar area was calculated by applying a special formula for tubular onion leaf [9].

Paper area $=-93.1+1.83 x$ Paper length $+38.6 x$ Paper circumference at a distance of $25 \%$ from its base. Measure the length and perimeter of the leaf (at a distance of $25 \%$ from the base of the leaf) by measuring tape of three leaves of different plants from each experimental unit (the fourth or fifth leaf is taken) and then take the average For one leaf, one leaf area (cm ${ }^{2}$ ) was extracted according to the above equation and then the leaf area of one plant was extracted according to the following equation:

Leafy area per plant $\left(\mathrm{cm}^{2}\right)=\frac{\text { area per leaf }\left(\mathrm{cm}^{2}\right)}{100} \quad \mathbf{X}$ Number of leaves per plant

- $\quad$ Fresh weight of consumed portion $(\mathrm{g})$ : Take the vegetative total of 5 plants from each experimental unit at harvest.

- $\quad$ Dry weight of the consumed part $(\mathrm{g})$ : the weight of the dry weight of the consumed part of 5 plants from each experimental unit, after placing in the oven (oven) at a temperature of $70^{\circ} \mathrm{C}$ until the stability of the weight [14].

- $\quad$ Bulb diameter $(\mathrm{cm})$ : Measure the diameter of the bulb using the foot (vernier) of the width of the area.

- Total yield of bulbs (ton / ha):

- According to the total production by the following equation:

Total bulb yield per ton $=$ average weight of onion in grams $\mathrm{x}$ number of plants in hectare

$1000 \times 1000$

Determination of percentage of total dissolved solids (TSS): This characteristic was measured at the plant department of the Faculty of Science / Zawia University by taking the sample and squeezed with a manual juicer and then placed drops of juice on the lens of the hand refractometer produced by the Italian company Prodit Engineering S.p.A.

\section{Statistical Analysis}

The RCBD design was used with three replicates and resulted in coefficients and replicates $12(4 \times 3)$ experimental units the mean was compared to all traits according to LSD test and the probability level was 0.05 .

\section{RESULTS AND DISCUSSION}

Table-3: Shows the effect of the types of fertilizers used in plant length, number of leaves per plant, bulb diameter and total leaf area $\left(\mathrm{cm}^{2}\right)$. Averages that share the same alphabet have no significant differences below the probability level of 0.05

\begin{tabular}{|c|l|l|l|l|}
\hline Parameter Assessed & $\begin{array}{c}\text { Plant height } \\
(\mathbf{c m})\end{array}$ & Number of leaves & $\begin{array}{c}\text { Bulb diameter } \\
(\mathbf{c m})\end{array}$ & $\begin{array}{c}\text { Total leaf } \\
\text { area (DSM) }\end{array}$ \\
\hline Organic 10 tons / ha & $68 \mathrm{bc}$ & $8.67 \mathrm{~b}$ & 1.68 & $9.38 \mathrm{c}$ \\
\hline Chemical & $77.22 \mathrm{ab}$ & $10.33 \mathrm{a}$ & 3.08 & $14.79 \mathrm{~b}$ \\
\hline Organic 20 tons / ha & $83.06 \mathrm{a}$ & $11 \mathrm{a}$ & 4.18 & $20.68 \mathrm{a}$ \\
\hline Comparison & $64.06 \mathrm{c}$ & 9 & $2.69 \mathrm{~b}$ & $2.69 \mathrm{~b}$ \\
\hline
\end{tabular}

In Table-3: The significant effect of the type of fertilizer used was show organic manure (decomposed sheep residue at 20 ton / ha, maximum values where averages were $83.06 \mathrm{~cm}, 11$ leaves, $4.18 \mathrm{~cm}, 20.68 \mathrm{~cm}^{2}$ for each plant length, number of leaves per plant, bulbdiameter and total leaf area respectively. Followed by treatment with compound chemical fertilizer $(0: 27: 27)$ where the averages were $77.22 \mathrm{~cm}, 10.33$ leaves, $3.08 \mathrm{~cm}$ and $14.79 \mathrm{~cm}^{2}$ for all the previous traits respectively, with no significant differences between them and the highest values resulting from organic fertilization 20 tons / ha. The length of the plant and the diameter of the onion. While there was no significant effect of organic fertilizer 10 tons / ha compared to the control except in the quality of bulb diameter. 
The reason may be due to the transfer of processed food to the part stored in the plant (bulb) as the length and size of the plant increases and thus the weight of the onion formed, which ultimately led to an increase in the total yield [20] and these results are consistent with the results obtained [21] in his study On the potato plant.

Table-4: Shows the effect of the types of fertilizers used in the fresh and dry weight of the consumed portio
production and TSS ratio
\begin{tabular}{|r|l|l|l|l|}
\hline Parameter Assessed & $\begin{array}{c}\text { Fresh weight of } \\
\text { the consumed } \\
\text { portion g } \\
\text { Treatment }\end{array}$ & $\begin{array}{c}\text { Dry weight of } \\
\text { the consumed } \\
\text { part g }\end{array}$ & $\begin{array}{c}\text { Production } \\
\text { ton / ha }\end{array}$ & Total TDS \\
\hline Organic 10 tons / ha & $46.88 \mathrm{c}$ & $8.13 \mathrm{bc}$ & $9.08 \mathrm{~b}$ & $10.2 \mathrm{a}$ \\
\hline Chemical & $72.57 \mathrm{~b}$ & $9.14 \mathrm{bc}$ & $12.79 \mathrm{a}$ & $10.3 \mathrm{a}$ \\
\hline Organic 20 tons / ha & $94.38 \mathrm{a}$ & $11.97 \mathrm{a}$ & $13.3 \mathrm{a}$ & $10.3 \mathrm{a}$ \\
\hline Comparison & $33.86 \mathrm{c}$ & $6.86 \mathrm{c}$ & $7.74 \mathrm{~b}$ & $9.91 \mathrm{~b}$ \\
\hline
\end{tabular}

Averages that share the same alphabet have no significant differences below the probability level of 0.05

Table 4 shows that there were no significant differences between the three fertilizer treatments on the percentage of total soluble solids with significant difference between them and the control. Also, there was no significant difference between organic fertilizer treatment of 20 tons / ha and chemical fertilizer treatment in total yields per hectare where the average production was 13.3 and 12.79 tons/ ha, respectively. However, the least amount of production was 7.74 and 9.08 tons/ ha of control treatment and organic fertilizer 10 tons / ha respectively with no significant differences between them. The mean and dry weight of the consumed portion were the organic superiority of the organic 20 tons / ha with averages of $94.3 \mathrm{~g}$ and $11.97 \mathrm{~g}$ respectively. The lowest weight for comparison was $33.8 \mathrm{~g}$ and $6.86 \mathrm{~g}$ with no significant difference between it and organic fertilizer 10 ton / ha. It recorded $46.8 \mathrm{~g}$ and $8.13 \mathrm{~g}$ for both fresh and dry weight of the consumed part respectively.

The increase in vegetative growth characteristics such as the soft and dry weight of the plant as a result of the addition of organic fertilizer and sheep manure 20 tons / ha may be due to the role of organic fertilizer in improving the physical, chemical and biological properties of the soil and increase its water retention, especially since the soil of the experiment field is sandy soil in addition to increasing their content of nutrients Zoubi et al. [22]. These all led to the formation of significant vegetative growth that increased the leafy area of the plant. So, the soft and dry weight of the plant increased. These results are in line with what Magdi found in [23].

\section{CONCLUSION}

The results indicate that the productivity of the organically cultivated area exceeds that of conventional methods. It also indicates that the cost of producing organic products is lower than that of traditional agriculture.

\section{REFERENCES}

1. Matlob, A. N., Sultan, E., \& Abdul, K. S. (1989). Vegetable Production. Dar Al-Kutub Publ., Mosul Univ., Iraq.

2. Patil, B. S., L. M. Pike, and K. S. Yoo. (1995). Variation in the quercetin content in different colored onions (Allium cepa L.). J. Amer. Soc. Hort. Science, 120(6): 909.

3. Hasler, C. M. (1998). Functional food: Their role in disease prevention and health promotion. Food Tech. 52 (11): $63-70$.

4. Jone, D.P., Coates R.J., \& Flagg E.W. (1992). Glutathione in foods listed in the National Cancer Institute, s Health Habits and History Food Frequency Questionnaire, Nute. Cancer, 17: 57-75.

5. Cutler , R. ,K. Cutler , R. Crawford, C. R., Ramarathnam , N. Takeuchi, and H. Ochi, (1998) . The genox oxidative stress profile. American Chemical Society. Chapter, 18:188-190.

6. Sheela, C., K. Kumud, and K. Augusti, (1995) . Anti-diabetic effects of onion and garlic sulfoxid amino acids in rats. Planta Med. 61: 356-357.

7. Arab Organization for Agriculture and Development, (2014). Agricultural Statistics Yearbook - Volume 34 - Khartoum, Sudan.

8. Fekry, Wafaa, A. and E. H. AbouEl- Salehein. (2010). Influence of different sources of fertilizers and yeast on growth, chemical composition, yield and its quality of onion plants. J. Product \& Dev., 15(3) : 403-423.

9. Mahmoud, M.R, (2006). Effect of some organic and inorganic nitrogen fertilizers on onion plants grown on a sandy calcareous soil. Assiut J. Agric. Sci., Egypt, 37(1): 147-159.

10. El-Bassiony .A.M., Fawzy, Z.F and S.A. Saleh. (2007). Effect of chemical fertilizer, poultry manure and biofertilizer on growth, yield and chemical contents of tomato plants. J. Agric. Sci., Mansoura Univ, Egypt, 32(8):6583-6594.

11. Blay , E.T. , E.Y.Danquaba and A. J. Ofosu-Anim. (2002). Effect of poultry manure and / or inorganic fertilizer on the yield of shallot ( Allinm cepa var. aggregatum ). Adv. In Hort. Sci. 1:13-16. 
12. Abdelrazzag. A, (2002). Effect of chicken manure, sheep manure and inorganic fertilizer on yield and nutrients uptake by onion. Pakistan J. Bio.Sci. 5(3):266-268.

13. Aisha, A. H., Rizk, F. A., Shaheen, A. M., \& Abdel-Mouty, M. M. (2007). Onion plant growth, bulbs yield and its physical and chemical properties as affected by organic and natural fertilization. Research Journal of Agriculture and Biological Sciences, 3(5), 380-388.

14. Kushla F. N. A., E. H. Abou El-Salehein and Ahlam, Rashed, F. Rashed. (2014). Effect of chemical, bio and organic fertilizers on growth and yield and bulb qualily of onion plants grown in Zawia region, Libya. J. Product. \& Dev., 19(2):113 - 122

15. Boyhan, G. E., \& Hill, C. R. (2008). Organic fertility sources for the production of short-day organic onion transplants. HortTechnology, 18(2), 227-231.

16. Akoun, J. (2004). Effect of plant density and manure on the yield and yield components of common onion (Allium cepa L.) var. Nsukka Red .Nigerian J. Hort. Sci. 9, 43-48.

17. Yassen, A.A. and K. A. Khalid. (2009). Influence of organic fertilizers on the yield, essential oil and mineral content of onion. Int. Agrophysics, 23:183-188.

18. Zedan K. G, (2011). Effect of organic manure and harvest date on growth and yield of onion. J. Tikrit Univ. Agric. Sci. 11(1) : 26327

19. Gamiely, S., W. M. Randle, H. A. Mills., \& D. A. Smittle, (1991). A rapid and nondestructive method for estimating leaf area of onion. Hort Science, 26(2):206.

20. Hassan and Ahmed Abdel Moneim. (2000). Production of onions and garlic. A series of vegetable crops, production technology and advanced agricultural practices. Arab Publishing House.

21. Zahawi and Samir Mohammed Ahmed. (2007). The Effect of Different Organic Fertilizers and Soil Coverage on Growth, Production and Quality of Potato Solanum tuberosum L. Master Thesis - Horticulture Department - College of Agriculture Baghdad University - Iraq.

22. Mousa, M. A., \& Mohamed, M. F. (2009). Enhanced yield and quality of onion (Allium cepa L. cv Giza 6) produced using organic fertilization. Ass. Univ. Bull. Environ. Res, 12(1), 9-19.

23. Zu'bi, Mohammed Manhal, Haitham Abdul and Mohammed Barham. (2007). Study of the effect of organic and bio fertilizer on potato productivity and some soil properties (Tartous governorate). Damascus University Journal for Agricultural Sciences. 162-151: (2) 23.

24. Yassen, A. A., \& Khalid, K. A. (2009). Influence of organic fertilizers on the yield, essential oil and mineral content of onion. Int. Agrophysics, 23, 183-188. 